\title{
Genetic Analysis of Spore Germination Mutants of Bacillus subtilis 168: the Correlation of Phenotype with Map Location
}

\author{
By ANNE MOIR, EILEEN LAFFERTY AND D. A. SMITH \\ Department of Genetics, University of Birmingham, P.O. Box 363, Birmingham B15 2TT
}

\author{
(Received 21 September 1978)
}

\begin{abstract}
The isolation and characterization of 29 new germination (Ger) mutants of Bacillus subtilis 168 is described. These were classified, along with previously described mutants, into seven groups according to map location. The mutations in 26 GerA mutants mapped between cys $B$ and $t h r$; detailed mapping of two of these has located them very close to citG. These mutants were deficient in germination in alanine, but responded to the germinative combination of asparagine, glucose, fructose and $\mathrm{KCl}$. One GerB mutant mapped on the origin-proximal side of hisA; it was normal in germination in alanine, but deficient in germination in a mixture of asparagine, glucose, fructose and $\mathrm{KCl}$. Two GerC mutants were linked to $l y s$, but were separable from a temperature-sensitive growth deficiency mapping between lys and trp. The GerC mutants had a similar germination phenotype to the GerA mutants. Three GerD mutants did not germinate in either of the above germinants or in Penassay Broth. They were located on the side of ery distal to cys A. The GerE mutant, which did not germinate in any of the three germinants, was located very close to cit $F$ and possessed an altered spore coat. The two GerF mutants were defective in germination in all three germinants and mapped on the origin proximal-side of his $A$, but much closer to his than did the GerB mutant. A phosphoglycerate kinase-negative mutant altered in germination mapped between $c y s B$ and his $A$ (GerG). These mutants have established a minimum of seven locations important to germination, and will be useful in the development and appraisal of theories of spore germination.
\end{abstract}

\section{INTRODUCTION}

The differentiation process in a spore-forming bacterium is complex. It involves the formation of a dormant and resistant spore, its release from the dormant state (germination of the spore) and its subsequent outgrowth into a vegetative cell. Mutants defective in sporulation (Piggot \& Coote, 1976), germination (Wax et al., 1967; Trowsdale \& Smith, 1975; Vary, 1975; Foerster, 1971) and outgrowth (Nukushina \& Ikeda, 1969; Galizzi et al., $1973,1975)$ are being used to analyse this process and its control.

Germination of the bacterial spore is accompanied by changes in the structure and metabolic capacity of the spore (Gould, 1969) and can proceed in the presence of inhibitors of transcription and translation (Keynan \& Halvorson, 1965). It can be induced by chemical or physical stimuli. Amino acids, nucleosides and sugars are common chemical germinants; Bacillus subtilis 168, for example, is stimulated to germinate by a number of amino acids, alanine being particularly effective (Woese et al., 1958). Germination mutants, in which spore germination does not proceed at the normal rate in response to germinants, have been obtained in a number of Bacillus species, but only in a few cases has a corresponding (and perhaps causative) biochemical defect been identified (Foerster \& Foerster, 
1973; Prasad et al., 1972). The study of such mutants can provide information on requirements for germination and relationships between different germinants. The isolation of germination mutants in $B$. subtilis 168 has permitted some genetic analysis and they have been shown to result from mutations at one of several locations on the chromosome (Trowsdale et al., 1974; Trowsdale \& Smith, 1975; Lafferty \& Moir, 1977; Smith et al., 1977; Smith et al., 1978). This paper describes the isolation, phenotypic characterization, mapping and attempted classification of a spectrum of germination mutants of $B$. subtilis 168.

\section{METHODS}

Bacterial strains. All strains were derivatives of Bacillus subtilis 168 (Table 1). Germination mutants described in this paper (Table 2) include six of those isolated by Trowsdale \& Smith (1975) which have been studied further. All mutants were derived by mutagenesis of strain 1604, except for 1484, 1498, 1503, 1487, 1488, 1558 and 4548 which were derived from strain 1408.

Media. Difco Penassay Broth (PAB) was used as a liquid growth medium. Solid media were potato glucose yeast extract (PGYE agar; Dring \& Gould, 1971) and Tryptose Blood Agar Base (TBAB; Difco) solidified with $1.5 \%$ (w/v) Oxoid no. 1 agar. TBAB top layer contained $1 \%$ agar. Minimal agar (MA; Anagnostopoulos \& Spizizen, 1961) contained glucose $\left(5 \mathrm{mg} \mathrm{ml}^{-1}\right)$ and was supplemented as necessary with amino acids $\left(50 \mu \mathrm{g} \mathrm{ml}^{-1}\right)$ except for arginine $\left(200 \mu \mathrm{g} \mathrm{ml}^{-1}\right)$. Sodium DL-lactate $\left(5 \mathrm{mg} \mathrm{ml}^{-1}\right)$ and Lalanine $\left(2 \mathrm{mg} \mathrm{ml}^{-1}\right)$ were used as alternative carbon sources. For growth of strain 61111 , L-malic acid, adjusted to $\mathrm{pH} 7.0$ with $\mathrm{NaOH}$, was added to $\mathrm{PAB}$ and TBAB at $5 \mathrm{~mm}$ and to MA at $10 \mathrm{mM}$. G agar was MA supplemented with $\mathrm{CaCl}_{2}(60 \mu \mathrm{M}), \mathrm{MnCl}_{2}(100 \mu \mathrm{M})$, L-asparagine $(10 \mathrm{mM})$ and $\mathrm{D}$-fructose $\left(1 \mathrm{mg} \mathrm{ml}^{-1}\right)$. NA-bromocresol purple agar was the purification medium of Carls \& Hanson (1971).

Preparation of spores. This was as previously described (Lafferty \& Moir, 1977). PGYE agar was the medium usually employed for preparation of spores, but occasionally the resuspension method of Sterlini \& Mandelstam (1969) was used.

Germination studies. (i) The germination of spore suspensions was followed by measuring the fall in absorbance at $580 \mathrm{~nm}$. Readings taken at $15 \mathrm{~min}$ intervals over a $60 \mathrm{~min}$ period after addition of germinant were normalized to the initial value and represented graphically. This produced a curve describing the proportional fall in absorbance with time. Since a spore population is asynchronous with respect to the time of exposure to germinant before germination occurs (microlag) and since the actual duration of the germination-associated changes (microgermination) is short, the curve reflects the distribution of microlag time in the population. The term germination 'rate' is used in this paper to signify the maximum gradient of the curve; a steeper curve (narrower distribution of microlag) was correlated with a shorter mean microlag.

Germinants used included: L-alanine $(10 \mathrm{mM})$, ALA; L-asparagine $(10 \mathrm{mM})$, ASN; D-glucose $\left(1 \mathrm{mg} \mathrm{ml}^{-1}\right)$, GLC; D-fructose $\left(1 \mathrm{mg} \mathrm{m}^{-1}\right)$, FRU; $\mathrm{KCl}\left(10 \mathrm{mg} \mathrm{ml}^{-1}\right)$; PAB; SPAB, i.e. PAB + ALA + ASN + GLC+ FRU $+\mathrm{KCl}$. Germination was in $0 \cdot 1 \mathrm{M}-\mathrm{Tris} / \mathrm{HCl}$, $\mathrm{pH} 7 \cdot 4$, except when PAB or SPAB was used.

(ii) Most germination mutants (Ger-) could be distinguished from the wild type (Ger+) by the tetrazolium overlay technique, based on that of Lafferty \& Moir (1977). Spore-containing colonies on PGYE agar were exposed to chloroform vapour, then overlaid with agar containing 2,3,5-triphenyltetrazolium chloride. After incubation, the $\mathrm{Ger}^{+}$colonies appeared red as a result of reduction of the tetrazolium (Tzm-Red) while Ger- colonies remained unstained (Tzm-White). The response to tetrazolium was dependent on the efficiency of sporulation in the colony, and this was affected by some auxotrophic markers. $C y s B$ strains, for example, sporulated better and gave a clearer response in the test if PGYE agar was supplemented with cysteine.

(iii) In some cases, $\mathrm{Ger}^{+}$and $\mathrm{Ger}^{-}$phenotypes could be distinguished by replica plating after chloroform treatment to $\mathrm{G}$ agar and incubating at $25^{\circ} \mathrm{C}$ for $16 \mathrm{~h}$. The replicas of Ger- clones showed much fainter growth than those of $\mathrm{Ger}^{+}$clones, the distinction diminishing after further incubation at $25^{\circ} \mathrm{C}$.

Isolation of germination mutants. Exponential phase cultures of strain 1604 in PAB were either treated with $N$-methyl- $N^{\prime}$-nitro- $N$-nitrosoguanidine $\left(75 \mu \mathrm{g} \mathrm{ml}^{-1}\right)$ for $1 \mathrm{~h}$ at $37^{\circ} \mathrm{C}$, or resuspended in $100 \mathrm{mM}$ $\mathrm{MgSO}_{4}$ and irradiated with ultraviolet light $(0.1 \%$ survival). Samples $(0.2 \mathrm{ml})$ of undiluted and 10 -fold diluted mutagenized cultures were used to prepare spores as described above. The procedures for enrichment for germination mutants were described by Lafferty \& Moir (1977). Several mutants were retained from the same mutagenized culture only if their germination phenotypes were clearly different.

Transduction. Phage PBS1 lysates were prepared and used in transduction as described by Jamet \& Anagnostopoulos (1969). Transductants were selected and purified on the same selective medium and a single colony was used for determining unselected markers. $\mathrm{Cit}^{+}$and phosphoglycerate kinase ${ }^{+}\left(\mathrm{PGK}^{+}\right)$ recombinants were selected for their ability to grow on MA plus lactate and MA, respectively, and were 
Table 1. Strains of Bacillus subtilis 168

\begin{tabular}{|c|c|}
\hline Strain designation & Genotype \\
\hline 1408 & $\operatorname{trp} C 2$ \\
\hline BD111 & cysB3 thr -5 trp $C 2$ \\
\hline SB137 & aroB2 hisH2 \\
\hline 1696 & trp hisH2 \\
\hline 1604 & $\operatorname{trp} C 2$ \\
\hline BD 92 & cysB3 hisAl trpC2 \\
\hline 1621 & nov-3 trpC2 \\
\hline 4650 & cysB3 nov-3 trpC2 \\
\hline 60229 & ald trpC2 \\
\hline 61111 & $\mathrm{PGK}^{-}$met trp \\
\hline BD163 & hisAl $\arg C 4$ \\
\hline 1420 & hisAl \\
\hline BD112 & cys $A 14$ \\
\hline 4248 & cys $A 14$ ery- $I$ \\
\hline 4620 & cys $A 14$ ery- 1 trpC 2 \\
\hline Mu8u5u16u24 & leuA8 metB5 purA16 sacA24 \\
\hline 1612 & metB5 arol906 sacA321 dal \\
\hline GSY254 & lys-1 trpC2 \\
\hline 1506 & lys -1 \\
\hline BD40 & phe-12 $\arg A 3$ \\
\hline GSY374 & leuA8 \\
\hline WB2281b & aroA \\
\hline JH402 & citF2 trpC2 \\
\hline JH326 & citF78 leu \\
\hline JH404 & citG4 trpC2 \\
\hline
\end{tabular}

Trowsdale \& Smith (1975)

D. Dubnau

Nester et al. (1963)

J. Trowsdale. Aro ${ }^{+}$and Trp ${ }^{-}$transduced into SB137

$\mathrm{Cys}^{+}$and $\mathrm{Thr}^{+}$from 1696 transduced into BD111

C. Anagnostopoulos

Thy ${ }^{+}$revertant of VUB33

(Trowsdale \& Anagnostopoulos, 1976)

Nov $^{\mathrm{R}}$ and $\mathrm{Thr}^{+}$from 1621 transduced into BD111

E. Freese

Freese et al. (1972)

D. Dubnau

From BD163

D. Dubnau

Goldthwaite et al. (1970)

Cys $^{-}$and Ery ${ }^{\mathrm{R}}$ from 4248 transduced into 1604

N. Sueoka

J. Lepesant

C. Anagnostopoulos

Trp $^{+}$revertant of GSY254

D. Dubnau

C. Anagnostopoulos

E. W. Nester

Ohné et al. (1973)

Ohné et al. (1973)

Rutberg \& Hoch (1970)

washed in minimal salts before plating. Antibiotic resistance was scored on TBAB agar plus erythromycin $\left(1 \mu \mathrm{g} \mathrm{ml}^{-1}\right)$ or novobiocin $\left(2 \mu \mathrm{g} \mathrm{ml}^{-1}\right)$.

Determination of the germination phenotype of transductants. For large numbers of transductants the tetrazolium overlay reaction was used, except where otherwise stated. To confirm the validity of this method for the donor and recipient strains concerned, the germination characteristics of spore suspensions of at least six Ger+ and Ger- recombinants were determined for each mutant mapped. The variation in both the germination phenotype and tetrazolium response of spores of different $B$. subtilis 168 strains can be as great as that between the wild type and germination mutants. Wherever possible, recipient strains whose spores germinated and gave the same tetrazolium reaction as the $\mathrm{Ger}^{+}$strain 1604 were used.

\section{RESULTS}

\section{Choice of "wild-type' strain}

Neither $\mathrm{Ger}^{+}$nor $\mathrm{Ger}^{-}$phenotypes could be selected; reliability of the tetrazolium overlay reaction was essential for recognizing and scoring germination defects (Trowsdale \& Smith, 1975; Lafferty \& Moir, 1977). It was therefore necessary to use a Ger ${ }^{+}$starting strain which grew, sporulated and germinated normally and which reduced 2,3,5-triphenyltetrazolium chloride efficiently, becoming dark red on incubation after overlay. Trowsdale \& Smith (1975) were aware that their $B$. subtilis 168 wild-type strain 1408 did not meet all these criteria. However, they showed that some ger mutations were linked to $c y s B$ and that the Ger+ and $\mathrm{Ger}^{-}$phenotypes of $\mathrm{Cys}^{+}$transductants of BD111 (Table 1) could be clearly distinguished both by the germination ability of washed spore suspensions and by the tetrazolium reaction. Thus $\mathrm{Cys}^{+}$transductants of BD111 satisfied our conditions, and moreover, BD111 would be an appropriate strain into which to transfer cysB-linked germination mutations. It was therefore used as the major genetic background of the Ger starting 'wild-type'. The cysteine requirement of BD111 was removed by transduction to $\mathrm{Cys}^{+} \mathrm{Thr}^{+}$using a lysate grown on strain 1696 (Table 1). The germination characteristics of spores of this strain (1604) are shown in Fig. 1. Spores responded well to all germinants 

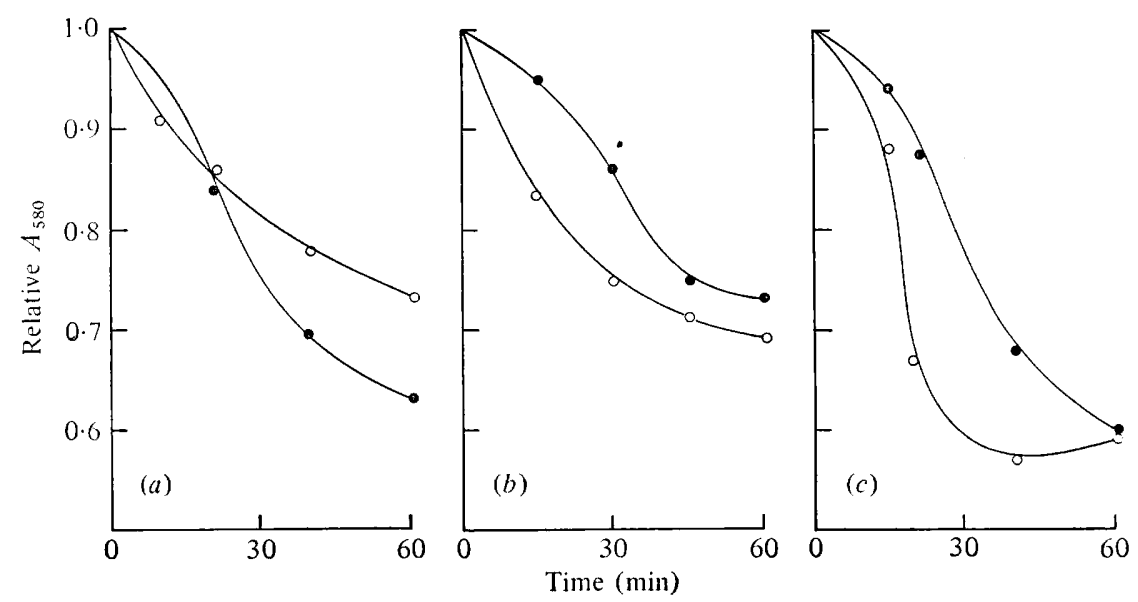

Fig. 1. Germination of spore suspensions of strain 1604. Spores produced on PGYE agar at $42{ }^{\circ} \mathrm{C}$ were germinated at $25^{\circ} \mathrm{C}(\bullet)$ and $42{ }^{\circ} \mathrm{C}(O)$ in: $(a) 0 \cdot 1 \mathrm{M}$-Tris/HCl, pH 7.4, containing L-alanine $(10 \mathrm{mM}) ;\left(\right.$ b) $0 \cdot 1 \mathrm{M}$-Tris $/ \mathrm{HCl}$, pH 7.4, containing L-asparagine $(10 \mathrm{~mm})$, D-glucose $\left(1 \mathrm{mg} \mathrm{ml}^{-1}\right)$, D-fructose $\left(1 \mathrm{mg} \mathrm{ml}^{-1}\right)$ and $\mathrm{KCl}\left(10 \mathrm{mg} \mathrm{ml}^{-1}\right)$; (c) Penassay Broth.

tested, except that spores prepared at $25^{\circ} \mathrm{C}$ germinated poorly in $\mathrm{ASN}+\mathrm{GLC}+\mathrm{FRU}+\mathrm{KCl}$ at $25^{\circ} \mathrm{C}$. Heat activation stimulated the rate of, but was not essential for, germination of strain 1604. Most of the spore germination mutants were derived from this strain.

\section{Germinants}

Three germinants were chosen. (i) L-Alanine - this is the amino acid to which spores of B. subtilis 168 respond most sensitively (the rate of germination is further enhanced if $\mathrm{KCl}$ is added). (ii) A mixture of L-asparagine, D-glucose, D-fructose and $\mathrm{KCl}$-germination is induced only if all four components are present and these may satisfy the same metabolic requirements for germination as alanine (Wax \& Freese, 1968); thus germination mutants altered in response to alanine might remain normal for the mixture, and vice versa. (iii) Penassay Broth - this is a complex medium in which a number of compounds whose nature has not been determined may be involved in germination.

\section{Mutant isolation}

After mutagenesis of vegetative cells and subsequent enrichment of their spores for germination mutants in ALA, PAB or SPAB, colonies from surviving spores were picked and purified on TBAB. Their spore germination phenotype was then tested by the tetrazolium reaction and by replica plating. Spores were produced from those isolates ( 1 to $10 \%$ of the total) distinguishable from the wild type in this preliminary screening, and their germination response to different germinants was measured.

All the mutants isolated, except 4592 ( $(\mathrm{ger}-18)$, were Tzm-White; spores of all germinated poorly ( $<10 \%$ fall in absorbance in $60 \mathrm{~min}$ ) in at least one of the germinants. Their phenotypes are described in Table 2 . All the mutants grew normally on MA plus tryptophan, except for $4586\left(\mathrm{Thr}^{-}\right), 4600$ (His $^{-}$) and 4521 (cold sensitive for growth). The germination mutations could be separated by PBS1 transduction from the mutations responsible for these phenotypes.

The type of germination mutant obtained was influenced by the nature of the germinants used. Enrichment in ALA resulted in isolation of mutants which germinated in ASN + $\mathrm{GLC}+\mathrm{FRU}+\mathrm{KCl}$ but not in ALA. Enrichment in PAB resulted not only in mutants of this Ger- phenotype, but also one which germinated in ALA but not in ASN+GLC+ $\mathrm{FRU}+\mathrm{KCl}$ and another which was defective in germination in all three germinants; five 
Table 2. Origin and properties of germination mutants

\begin{tabular}{|c|c|c|c|c|c|c|}
\hline \multirow[b]{2}{*}{$\begin{array}{c}\text { Strain } \\
\text { designation }\end{array}$} & \multirow[b]{2}{*}{ Mutation } & \multirow[b]{2}{*}{$\begin{array}{l}\text { Mutagen } \\
\text { used }\end{array}$} & \multirow[b]{2}{*}{ Enrichment } & \\
\hline & & & & PAB & $\begin{array}{c}\mathrm{ALA}+ \\
\mathrm{KCl}\end{array}$ & $\begin{array}{c}\mathrm{ASN}+\mathrm{GLC}+ \\
\mathrm{FRU}+\mathrm{KCl}\end{array}$ \\
\hline 4522 & ger -1 & UV & ALA & + & - & + \\
\hline 4507 & ger-2 & $\mathrm{NG}$ & ALA & + & hs & + \\
\hline 4582 & ger-3 & UV & PAB & \pm & - & + \\
\hline 4514 & ger -4 & NG & PAB & \pm & - & + \\
\hline 4502 & ger -5 & $\mathrm{NG}$ & PAB & $\overline{ \pm}$ & - & + \\
\hline 4521 & ger- 6 & $\mathrm{NG}$ & PAB & \pm & - & + \\
\hline 4583 & ger-7 & UV & PAB & \pm & - & + \\
\hline 4584 & ger -8 & UV & PAB & \pm & - & + \\
\hline 4506 & ger -9 & NG & ALA & \pm & - & + \\
\hline 4505 & ger -10 & $\mathrm{NG}$ & $\mathrm{PAB}$ & $\overline{ \pm}$ & - & + \\
\hline 4585 & ger -11 & UV & SPAB & - & - & + \\
\hline 4586 & ger -12 & UV & SPAB & hs & hs & + \\
\hline 4587 & ger -13 & UV & SPAB & - & - & + \\
\hline 4588 & ger-14 & UV & SPAB & - & - & + \\
\hline 4589 & ger-15 & NG & PAB & - & - & + \\
\hline 4590 & ger -16 & NG & $\mathrm{PAB}$ & hs & hs & + \\
\hline 4592 & ger -18 & UV & PAB & + & + & - \\
\hline 4593 & ger -19 & UV & SPAB & - & - & - \\
\hline 4594 & ger -20 & UV & SPAB & - & - & - \\
\hline 4595 & ger -21 & UV & $\mathrm{PAB}$ & - & - & - \\
\hline 4518 & ger-26 & $\mathrm{NG}$ & PAB & \pm & - & + \\
\hline 4504 & ger-28 & NG & PAB & \pm & - & + \\
\hline 4500 & ger -29 & NG & ALA & \pm & - & + \\
\hline 4512 & ger -31 & NG & PAB & \pm & - & + \\
\hline 4510 & ger -32 & UV & ALA & \pm & - & + \\
\hline 4548 & ger -35 & $\mathrm{NG}$ & ALA & + & - & + \\
\hline 4600 & ger -36 & UV & SPAB & - & - & - \\
\hline 4601 & ger -37 & UV & SPAB & - & - & - \\
\hline 4728 & ger -45 & UV & SPAB $\uparrow$ & - & - & - \\
\hline 1484 & ger -84 & NG & ALA & + & - & + \\
\hline 1498 & ger -98 & NG & PAB & \pm & - & + \\
\hline 1503 & ger-89 & NG & PAB & \pm & - & + \\
\hline 1487 & ger-87 & NG & PAB & \pm & - & + \\
\hline 1488 & ger -88 & $\mathrm{NG}$ & PAB & + & hs & + \\
\hline 1558 & ger -58 & NG & PAB & + & hs & + \\
\hline
\end{tabular}

UV, Ultraviolet light; NG, $N$-methyl- $N^{\prime}$-nitro- $N$-nitrosoguanidine; ALA, Tris/HCl containing Lalanine; PAB, Penassay Broth; SPAB, PAB containing L-alanine, L-asparagine, D-glucose, D-fructose and $\mathrm{KCl}$; ASN + GLC + FRU + KCl, Tris/ $\mathrm{HCl}$ containing L-asparagine, D-glucose, D-fructose and $\mathrm{KCl}$.

* Germination rates relative to wild-type spores: $+=>50 \%, \pm=15$ to $50 \%,-=<15 \%$. hs, Germination rate slower at $42^{\circ} \mathrm{C}$ than at $25^{\circ} \mathrm{C}$.

+ Spores produced by the resuspension method.

out of 15 of the mutants from this enrichment germinated well in PAB. Enrichment in SPAB resulted in approximately equal proportions of mutants responsive to neither ALA nor PAB and mutants not germinating in any of the three test germinants. Although the enrichment procedures did not yield only the anticipated types of mutant, a higher proportion of the mutants were unresponsive to a wide range of germinants when several germinants were present during the enrichment.

\section{Phenotypes and mapping of Ger mutants}

The genetic and physiological analysis enabled the assignment of mutants to groups GerA to GerG according to phenotype and map location (Lafferty \& Moir, 1977; Smith et al., 1977; Smith et al., 1978). These phenotypic designations, which also reflect approximate map location, are not equivalent to genotypes and are regarded as a temporary convenience. 

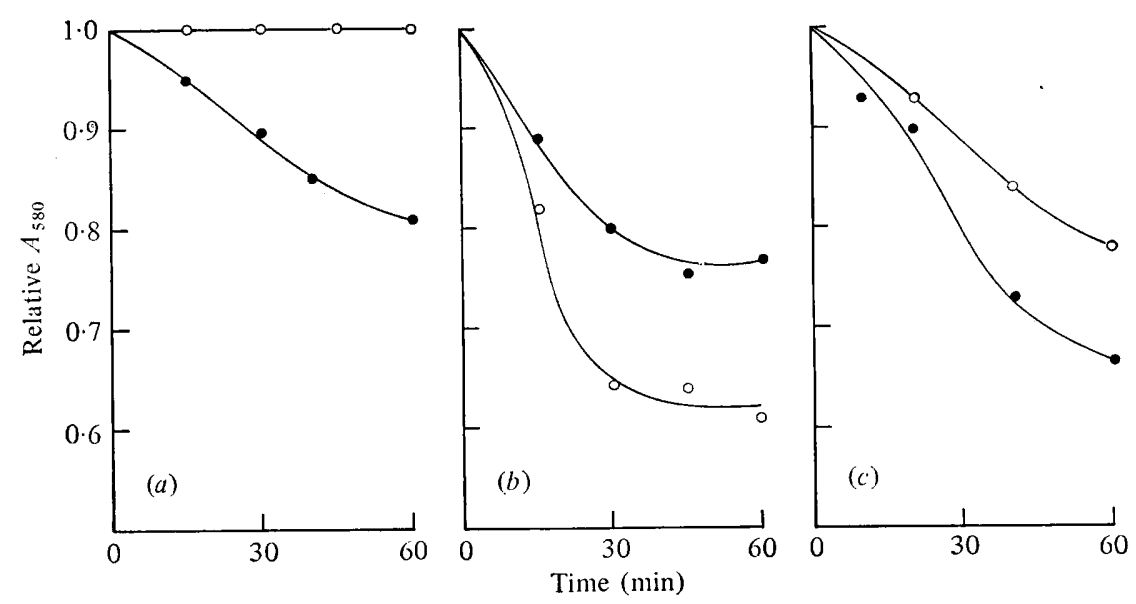

Fig. 2. Germination of spore suspensions of strain 4586 (ger-12). Details as in Fig. 1 legend.

\section{Mutants in which germination is conditional on the nature of the germinant}

Ger $A$ mutants. Strains carrying the mutations ger-1 to -16 inclusive and ger-26, $-28,-29$, $-31,-32$ and -35 , along with ger- $-84,-86,-87,-89,-97$ and -98 of Trowsdale \& Smith (1975) form a distinct phenotypic group. All failed to germinate in $\mathrm{ALA}+\mathrm{KCl}$, but responded well to ASN + GLC+FRU + KCl. Their response to PAB varied from that of wild type (ger-l) through intermediate levels (ger-4) to less than $10 \%$ of wild type (ger-11). As indicated in Table 2 , the germination of several mutants was heat-sensitive; they germinated less well at $42{ }^{\circ} \mathrm{C}$ than at $25^{\circ} \mathrm{C}$. Strain 4586 (ger-12), for example, was heat-sensitive in ALA and to some extent in PAB (Fig. 2). Mutants which germinated to an intermediate extent in $\mathrm{PAB}$ responded less efficiently at $26^{\circ} \mathrm{C}$ than at $42^{\circ} \mathrm{C}$; since the Ger strain 1604 also responded more quickly at $42{ }^{\circ} \mathrm{C}$ than at $26^{\circ} \mathrm{C}$ (Fig. 1), it was not possible to define the degree of cold sensitivity attributable to the ger mutation. Where tested (ger-1, $-2,-5$, $-6,-9,-10,-26$ and -28$)$ the spores of GerA mutants did not germinate in L-valine (10 mM) or $\alpha$-aminobutyrate $(10 \mathrm{~mm})$.

The addition to ALA $+\mathrm{KCl}$ of GLC+FRU stimulated germination of all of these mutants. The addition of GLC alone sometimes resulted in partial germination, especially if the spores were produced at $42{ }^{\circ} \mathrm{C}$ (Fig. 3). Because of this dependence on sporulation temperature it is difficult to classify mutants according to whether they require FRU in addition to GLC for germination in ALA $+\mathrm{KCl}$, although this distinction has previously been employed (Trowsdale \& Smith, 1975; Lafferty \& Moir, 1977).

Six of the nine germination mutants described by Trowsdale \& Smith (1975) share phenotype and map location with the other GerA mutants. Of these (Table 2), strain 1484 is included because ger-84 has now been mapped (Table 3) and 1487, 1498 and 1503 are included because further work has revealed that they germinate as well as the wild type in $\mathrm{ASN}+\mathrm{GLC}+\mathrm{FRU}+\mathrm{KCl}$ and to a significant extent in PAB. Like the other mutants, the inability to germinate in ALA + $\mathrm{KCl}$ was overcome by the addition of GLC or GLC+FRU.

In order to map the ger mutations, phage lysates prepared on ger trpC2 mutants were used to transduce auxotrophic markers in Ger+ reference strains to prototrophy, and the germination phenotype of a random sample of transductants was tested by the tetrazolium overlay method. Co-transduction frequencies of ger mutations in strains of the GerA phenotype with $c y s B$ and his $A$ were determined (Table 3 ). In addition, BD111 was transduced to $\mathrm{Thr}^{+}$; the linkages to $t h r$ of ger $-1,-3,-7,-8,-15,-16$ and -84 were $40,39,42,49$, 43,41 and $36 \%$ respectively. Mutations ger-26, $-28,-29,-32$ and -35 were $33,20,12,25$ and $25 \%$ co-transduced with ald in crosses with strain 60229 as recipient. Co-transduction 


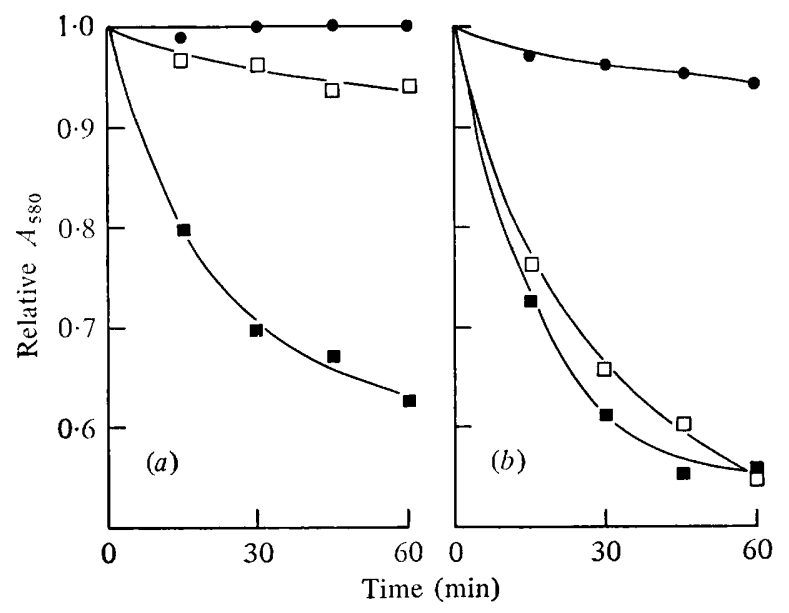

Fig. 3. Effect of temperature of spore formation on the germination of strain 4583 (ger-7). Spores produced on PGYE agar at $25^{\circ} \mathrm{C}(a)$ and $42^{\circ} \mathrm{C}(b)$ were germinated in $0.1 \mathrm{M}$-Tris/HCl, pH 7.4, containing L-alanine $(10 \mathrm{~mm})$ and $\mathrm{KCl}\left(10 \mathrm{mg} \mathrm{m}^{-1}\right)$ : $\bigcirc$, without further additions; $\square$, with Dglucose $\left(1 \mathrm{mg} \mathrm{ml}^{-1}\right) ; \mathbf{n}$, with $\mathrm{D}$-glucose $\left(1 \mathrm{mg} \mathrm{ml}^{-1}\right)$ and $\mathrm{D}$-fructose $\left(1 \mathrm{mg} \mathrm{ml}^{-1}\right)$.

\section{Table 3. Genetic analysis of group A germination mutants}

Co-transduction frequencies with $c y s B$ were obtained using strain $\mathrm{BD} 111$ as recipient and those with his $A$ using BD92 (for ger-1, $-3,-7,-9,-10$ and -16 ) or BD163 (all other ger mutations). Three factor crosses, selecting Cys ${ }^{+}$, were between BD111 as recipient and $g e r \operatorname{trp} C 2$ as donor except for the cross locating ger-12(*), in which $\mathrm{BD} 92$ was the recipient and ger-12 thr $\operatorname{trp} C 2$ was the donor.

Mutation
in donor
ger-1
ger-2
ger-3
ger-4
ger-5
ger-6
ger-7
ger-8
ger-9
ger-10
ger-11
ger-12
ger-13
ger-14
ger-15
ger-16
ger-26
ger-28
ger-29
ger-31
ger-32
ger-35
ger-84

Co-transduction $(\%)$ with

Three factor cross

\begin{tabular}{|c|c|c|c|c|c|}
\hline \multicolumn{2}{|c|}{ co-transciuction $(\%)$ wit } & \multicolumn{4}{|c|}{ per recomoin } \\
\hline cys $B$ & $h i s A$ & Thr $^{-} \mathrm{Ger}^{+}$ & Thr-Ger- & $\mathrm{Thr}^{+} \mathrm{Ger}^{+}$ & $\mathrm{Thr}^{+} \mathrm{Ger}^{-}$ \\
\hline 80 & 6 & 17 & 43 & 2 & 33 \\
\hline 78 & 7 & 18 & 25 & 0 & 38 \\
\hline 74 & 9 & 24 & 40 & 1 & 31 \\
\hline 70 & 2 & 20 & 32 & 1 & 18 \\
\hline 83 & 4 & 16 & 19 & 0 & 60 \\
\hline 77 & 8 & 18 & 30 & 0 & 32 \\
\hline 74 & 8 & 24 & 41 & 1 & 30 \\
\hline 81 & ND & 18 & 32 & 0 & 45 \\
\hline 75 & 13 & 17 & 20 & 0 & 31 \\
\hline 82 & 3 & 12 & 28 & 1 & 32 \\
\hline 76 & 6 & 23 & 41 & 1 & 35 \\
\hline 78 & 7 & $2 *$ & $21^{*}$ & $32 *$ & $41 *$ \\
\hline 77 & 6 & 23 & 54 & 0 & 24 \\
\hline 76 & 9 & 25 & 56 & 0 & 24 \\
\hline 80 & ND & 18 & 33 & 0 & 41 \\
\hline 69 & 12 & 29 & 51 & 1 & 15 \\
\hline 80 & 5 & 11 & 14 & 1 & 34 \\
\hline 86 & 9 & 12 & 20 & 0 & 52 \\
\hline 72 & ND & 22 & 25 & 1 & 33 \\
\hline 59 & ND & 31 & 20 & 0 & 25 \\
\hline 77 & ND & 19 & 33 & 1 & 30 \\
\hline 69 & ND & 24 & 38 & 1 & 17 \\
\hline 69 & ND & 23 & 25 & 1 & 29 \\
\hline
\end{tabular}

ND, Not done. 
Table 4. Three and four factor transduction crosses ordering ger, nov and cysB in group A germination mutants

$\mathrm{Thr}^{+}$transductants were selected in crosses between ger thr-5 trpC2 as donors and strains 1621 (nov-3 trpC2) and 4650 (cysB3 nov-3 trpC2) as recipients.

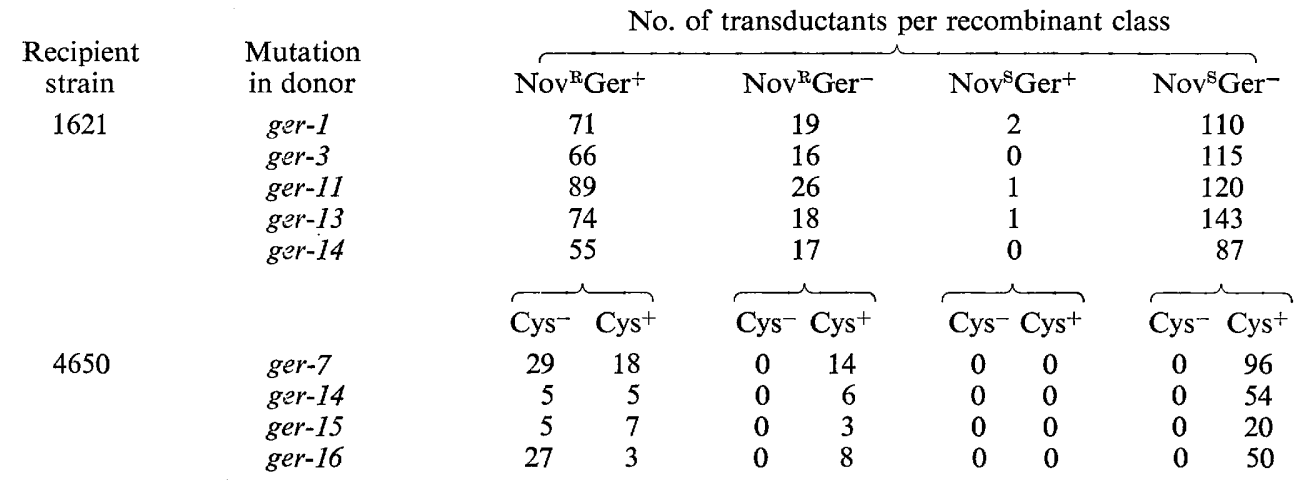

frequencies were calculated from a screening of 90 to 100 transductants in most crosses, but of only 60 to 90 transductants in 12 of the 23 crosses establishing linkage with cysB, in two of the 15 with his $A$ but in all five with ald. All GerA mutants contained ger mutations linked to cysB and to his $A$, thr and ald where tested. The mean co-transduction frequencies were: cysB $76 \%$, his $A 7 \%$, thr $41 \%$ and ald $23 \%$.

The presence in BD111 of two linked auxotrophic markers, cysB3 and thr-5, to which ger mutations were linked permitted the analysis of recombinant classes in a three factor cross (Table 3). In every cross, the members of one of the four possible combinations of unselected phenotypes were in a clear minority. The order of markers which would be responsible for the observed distribution was thr-ger-cys $B$ for each of the $23 \mathrm{GerA} \mathrm{mu-}$ tants tested. This conclusion was entirely consistent with the co-transduction frequencies obtained from two factor crosses and was supported for ger-1, -3, -6, -7, -8, -9, -10, -15 and -84 by the analysis of further three factor crosses (A. Moir, unpublished results). The order of genetic markers is therefore thr-ger-cys $B$; the higher co-transduction frequency with $c y s B$ would indicate that the ger mutations are located closer to $c y s B$ than to $t h r$.

Ger thr-5 trpC2 strains, constructed by transduction of $\mathrm{Cys}^{+}$and $\mathrm{Ger}^{-}$from ger trpC2 strains into BD111, were used as recipients in transduction crosses using strains 1621 or 4650 , carrying nov-3, as donors (Table 4). The distribution of recombinants amongst the possible phenotypic classes in three factor crosses clearly indicate that the sequence for ger- $1,-3,-11,-13$ and -14 is thr-nov-ger. The results of four factor crosses involving ger- 7 , $-14,-15$ and -16 were consistent with this deduction, although the number of recombinants from the cross involving ger-15 was low. Therefore, for all of the GerA mutants tested, the map location was thr-nov-ger-cys $B$ and no distinction could be made from these crosses between the map location of different GerA mutants.

Crosses were performed to compare the location of ger mutations with that of citG, which also maps between $t h r$ and $c y s B$ (Rutberg \& Hoch, 1970). Strains of genotype ger-3 cysB3 $\operatorname{trp} C 2$ and ger-7 cysB3 $\operatorname{trp} C 2$ were constructed by transduction of BD111 to $\mathrm{Thr}^{+}$ by lysates produced on ger $\operatorname{trp} C 2$ hosts. These strains were used as donors in three factor transduction crosses with $\mathrm{JH} 404$ as recipient (Table 5, crosses 1 and 2). CitG was cotransduced with ger-3 and ger-7 at a very high frequency (98 and 97\%, respectively). Because of this, there were too few $\mathrm{Cit}^{+} \mathrm{Ger}^{+}$recombinants to permit allocation of an unequivocal order to the ger, $c i t G$ and $c y s B$ genes. If the order were $c i t G-g e r-c y s B$, then Cys ${ }^{-} \mathrm{Ger}^{+}$recombinants should be less common than $\mathrm{Cys}^{+} \mathrm{Ger}^{+}$recombinants, because of the requirement for an increased number of crossover events in their formation. However, 
if the order were ger-citG-cysB, then there should be no rare class, and assuming an absence of interference effects, the proportions of $\mathrm{Ger}^{+}$and $\mathrm{Ger}^{-}$phenotypes amongst the Cys $^{-}$transductants should be similar to their proportions amongst the Cys ${ }^{+}$transductants. The distribution of phenotypes (Table 5) is most consistent with the order citG-ger-cysB, the evidence being stronger for ger-7 than for ger-3.

The GerB mutant. Ger-18 was the only mutation producing the phenotype of normal germination in $\mathrm{ALA}+\mathrm{KCl}$ and $\mathrm{PAB}$ but failure to germinate in ASN + GLC + FRU + $\mathrm{KCl}$ (Table 2). The concentration of ALA required to induce germination of ger-18 spores at half the maximal rate (Smith et al., 1978) was $80 \mu \mathrm{M}$, similar to that of the Ger ${ }^{+}$strain. The extent of germination in ASN + GLC + FRU $+\mathrm{KCl}$ (a $10 \%$ fall in absorbance in $60 \mathrm{~min}$ ) was not increased by raising the concentration of GLC or FRU by 10- or 100fold or of ASN by 10 -fold.

Spores of a mutant lacking fructose-1-phosphate kinase were unable to germinate in $\mathrm{ASN}+\mathrm{GLC}+\mathrm{FRU}+\mathrm{KCl}$ but did so if mannose was substituted for fructose (Prasad et al., 1972). Strains carrying ger-18 did not respond to this substitution although the wild type germinated equally well if either mannose or fructose was present. Thus the effect of $\mathrm{ger}-18$ on the germination phenotype is different from that of a fructose-1-phosphate kinase deficiency.

Strains carrying ger-18 were not distinguishable from the wild type by the tetrazolium reaction. However, a two factor cross using BD163 as recipient and ger- $18 \operatorname{trpC} 2$ as donor yielded $\mathrm{His}^{+}$transductants of two types which were distinguishable as slow- and fastgrowing in the germination replica plating test. Spores were produced from three transductants of each of the putative $\mathrm{Ger}^{+}$and Ger- classes; measurement of the germination response of spore suspensions in $\mathrm{ASN}+\mathrm{GLC}+\mathrm{FRU}+\mathrm{KCl}$ and $\mathrm{ALA}+\mathrm{KCl}$ confirmed the validity of the scoring technique and thus the $34 \%(39 / 116)$ co-transduction of ger-18 with hisA.

Differences in the auxotrophic markers present in transductants interfered with the scoring of $g e r-18$ by replica plating. Scoring by microscopic observation (Lafferty \& Moir, 1977) proved unreliable, and measurement of the fall in absorbance of fully washed spore suspensions was the only satisfactory method of scoring the germination phenotype of transductants in crosses between BD92 (cysB3 his 1 l trp C2) and ger-18 trpC2. Strain BD92 was transduced to $\mathrm{His}^{+}$and $\mathrm{Cys}^{+}$in separate experiments using phage produced on ger- 18 $\operatorname{trpC2}$. His $A$ and cysB were 15 to $20 \%$ co-transduced (A. Moir, unpublished results). The germination phenotypes of approximately equal numbers of transductants carrying wildtype and mutant alleles of the unselected auxotrophic marker were tested. From the selection for $\mathrm{Cys}^{+}, 8 \mathrm{His}^{+}$and $10 \mathrm{His}^{-}$transductants were tested; all were $\mathrm{Ger}^{+}$. From the selection for $\mathrm{His}^{+}, 12 \mathrm{Cys}^{+}$and $14 \mathrm{Cys}^{-}$were tested; all $12 \mathrm{Cys}^{+}$were $\mathrm{Ger}^{+}, 8 \mathrm{Cys}^{-}$were $\mathrm{Ger}^{+}$and $6 \mathrm{Cys}^{-}$were Ger-. No co-transduction of ger-18 with cys $B$ was detected in the $\mathrm{Cys}^{+}$recombinants tested, and three factor analysis of these crosses was therefore impossible. The co-transduction frequency with his $B$ and low co-transduction with $c y s B$ are consistent with the order cysB-hisA-ger-18.

GerC mutants. Two strains, 1488 (ger-88) and 1558 (ger-58), which did not germinate in ALA at $42{ }^{\circ} \mathrm{C}$ but did germinate in ASN + GLC + FRU + $\mathrm{KCl}$ were also altered in vegetative growth. They grew slowly on PGYE agar, particularly at high temperature, but normally on MA. The 'weird' growth phenotype (Wrd-) mapped near lys and was not separated from the defective germination phenotype in any of the 16 transductants tested by Trowsdale \& Smith (1975). These authors also found that mapping in this region was complicated by the presence in the wild-type strain 1408 (from which 1488 and 1558 were derived) of a mutation causing colonies to remain white after the tetrazolium overlay (Tzm-White) unlike the red colour developed by colonies of 1604 or 1506 .

In order to improve the analysis of the GerC mutants, transduction of strain 1506 by 
Table 5. Three factor transduction crosses establishing the location of ger mutations in groups $A, D, E, F$ and $G$ germination mutants

\begin{tabular}{|c|c|c|c|c|c|}
\hline $\begin{array}{c}\text { Cross } \\
\text { no. }\end{array}$ & Recipient & Donor & Selection & $\begin{array}{c}\text { Recombinant } \\
\text { class }\end{array}$ & $\begin{array}{l}\text { No. in } \\
\text { class }\end{array}$ \\
\hline 1 & $c i t G 4 \operatorname{trp} C 2$ & ger -3 cys $B 3$ trp $C 2$ & $\mathrm{Cit}^{+}$ & $\begin{array}{l}\text { Cys }^{+} \mathrm{Ger}^{+} \\
\text {Cys }^{+} \text {Ger }^{-} \\
\text {Cys-Ger }^{-} \\
\text {Cys }^{-} \text {Ger }^{-}\end{array}$ & $\begin{array}{r}3 \\
54 \\
1 \\
158\end{array}$ \\
\hline 2 & $c i t G 4 \operatorname{trp} C 2$ & ger-7 cys $B 3$ trp $C 2$ & $\mathrm{Cit}^{+}$ & $\begin{array}{l}\text { Cys }^{+} \text {Ger }^{+} \\
\text {Cys }^{+} \text {Ger }^{-} \\
\text {Cys }^{-} \text {Ger }^{+} \\
\text {Cys } \\
- \text { Ger }^{-}\end{array}$ & $\begin{array}{r}7 \\
82 \\
0 \\
182\end{array}$ \\
\hline 3 & $\mathrm{PGK}^{-}$met trp & cysB3 his $A 1 \operatorname{trp} C 2$ & $\mathrm{PGK}^{+}$ & $\begin{array}{l}\text { Cys }^{+} \text {His }^{+} \\
\text {Cys }^{+} \text {His }^{-} \\
\text {Cys }^{-} \text {His }^{+} \\
\text {Cys }^{-} \text {His }^{-}\end{array}$ & $\begin{array}{l}35 \\
24 \\
56 \\
32\end{array}$ \\
\hline 4 & cysB3 hisA1 trpC2 & PGK- met trp & His $^{+}$ & $\begin{array}{l}\text { Cys }^{+} \text {PGK }^{+} \\
\text {Cys }^{+} \text {PGK }^{-} \\
\text {Cys }^{-} \text {PGK }^{+} \\
\text {Cys }^{-} \text {PGK }^{-}\end{array}$ & $\begin{array}{r}2 \\
17 \\
62 \\
14\end{array}$ \\
\hline 5 & thr-5 cysB3 trpC2 & PGK- met trp & Thr $^{+}$ & $\begin{array}{l}\text { Cys }^{+} \text {PGK }^{+} \\
\text {Cys }^{+} \text {PGK }^{-} \\
\text {Cys }^{-} \text {PGK }^{+} \\
\text {Cys }^{-} \text {PGK }^{-}\end{array}$ & $\begin{array}{r}26 \\
14 \\
109 \\
0\end{array}$ \\
\hline 6 & cysA14 ery-1 & ger- $19 \operatorname{trpC2}$ & Cys $^{+}$ & $\begin{array}{l}\text { Ery }^{\mathrm{S}} \mathrm{Ger}^{+} \\
\text {Ery }^{\mathrm{s}} \mathrm{Ger}^{-} \\
\text {Ery }^{\mathrm{R}} \mathrm{Ger}^{+} \\
\text {Ery }^{\mathrm{R}} \mathrm{Ger}^{-}\end{array}$ & $\begin{array}{r}23 \\
170 \\
29 \\
2\end{array}$ \\
\hline 7 & cysA14 ery-1 & ger-20 trpC2 & Cys $^{+}$ & $\begin{array}{l}\text { Ery }^{\mathrm{s}} \mathrm{Ger}^{+} \\
\text {Ery }^{\mathrm{s}} \mathrm{Ger}^{-} \\
\text {Ery }^{\mathrm{R}} \mathrm{Ger}^{+} \\
\text {Ery }^{\mathrm{R}} \mathrm{Ger}^{-}\end{array}$ & $\begin{array}{r}21 \\
111 \\
7 \\
0\end{array}$ \\
\hline 8 & cysA14 ery-1 & ger-37 trpC2 & Cys $^{+}$ & $\begin{array}{l}\text { Ery }^{\mathrm{s}} \mathrm{Ger}^{+} \\
\text {Ery }^{\mathrm{s}} \mathrm{Ger}^{-} \\
\text {Ery }^{\mathrm{R}} \mathrm{Ger}^{+} \\
\text {Ery }^{\mathrm{R}} \mathrm{Ger}^{-}\end{array}$ & $\begin{array}{r}8 \\
176 \\
16 \\
1\end{array}$ \\
\hline 9 & ger-36 pheA12 & $\operatorname{leu} A 8$ & $\mathrm{Phe}^{+}$ & $\begin{array}{l}\text { Leu }^{+} \mathrm{Ger}^{+} \\
\text {Leu }^{+} \text {Ger }^{-} \\
\text {Leu }^{-} \text {Ger }^{+} \\
\text {Leu }^{-} \text {Ger }^{-}\end{array}$ & $\begin{array}{r}1 \\
153 \\
185 \\
41\end{array}$ \\
\hline 10 & ger $-36 \arg A 3$ & $\operatorname{leuA8}$ & $\mathrm{Arg}^{+}$ & $\begin{array}{l}\mathrm{Leu}^{+} \mathrm{Ger}^{+} \\
\mathrm{Leu}^{+} \mathrm{Ger}^{-} \\
\text {Leu }^{-} \mathrm{Ger}^{+} \\
\text {Leu }^{-} \mathrm{Ger}^{-}\end{array}$ & $\begin{array}{r}31 \\
221 \\
124 \\
0\end{array}$ \\
\hline 11 & citF2 trpC2 & ger-36 $\arg A 3$ & $\mathrm{Cit}^{+}$ & $\begin{array}{l}\mathrm{Arg}^{+} \mathrm{Ger}^{+} \\
\text {Arg }^{+} \mathrm{Ger}^{-} \\
\text {Arg }^{-} \mathrm{Ger}^{+} \\
\text {Arg } \\
\text {-Ger }\end{array}$ & $\begin{array}{r}7 \\
57 \\
0 \\
43\end{array}$ \\
\hline 12 & hisA1 & ger- 21 cys $B 3 \operatorname{trp} C 2$ & $\mathrm{His}^{+}$ & $\begin{array}{l}\text { Cys }^{+} \mathrm{Ger}^{+} \\
\text {Cys }^{+} \mathrm{Ger}^{-} \\
\text {Cys }^{-} \mathrm{Ger}^{+} \\
\text {Cys}{ }^{-}{ }^{-}{ }^{-}\end{array}$ & $\begin{array}{r}19 \\
190 \\
14 \\
64\end{array}$ \\
\hline 13 & hisA1 cysB3 trpC2 & ger $-45 \operatorname{trp} C 2$ & His $^{+}$ & $\begin{array}{l}\text { Cys }^{+} \text {Ger }^{+} \\
\text {Cys }^{+} \text {Ger }^{-} \\
\text {Cys }^{-} \text {Ger }^{+} \\
\text {Cys } \\
- \text { Ger }^{-}\end{array}$ & $\begin{array}{r}7 \\
47 \\
12 \\
83\end{array}$ \\
\hline
\end{tabular}


Table 6. Mapping of mutations in the lys-trp region

Lys $^{+}$transductants were selected in a cross between strain 1506 (Tzm-Red lys- 1 ) and 1558 (Tzm-White Wrd- ${ }^{-}$rpC2).

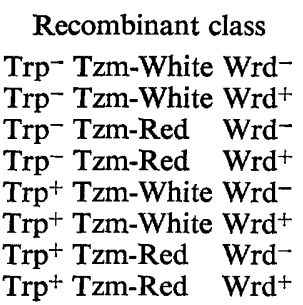

No. in class
163
3
1
1
19
0
66
28

lysates produced on 1558 was repeated. The Trp, Tzm and Wrd phenotypes of Lys ${ }^{+}$recombinants of strain 1506 were scored (Table 6). Their distribution between phenotypic classes was consistent with the order lys-wrd-tzm-trp. Since $\mathrm{Wrd}^{-}$strains did not grow on PGYE agar at 37 or $42{ }^{\circ} \mathrm{C}$, spores were prepared at $26^{\circ} \mathrm{C}$ from transductants of each common phenotype, and germination in ALA $+\mathrm{KCl}$ was measured at $42{ }^{\circ} \mathrm{C}$. $\mathrm{Wrd}^{+} \mathrm{Tzm}$ Red $\mathrm{Trp}^{+}$transductants (seven tested) germinated at the same rate as 1604 , the $\mathrm{Ger}^{+}$ Tzm-Red wild type; a Wrd-Tzm-Red Trp ${ }^{+}$transductant (one tested) germinated equally fast. Wrd-Tzm-White Trp ${ }^{+}$recombinants (five tested) germinated as fast as the Ger+TzmWhite strain 1408 from which the mutants were derived; the maximum rate of germination of strain 1408 was $50 \%$ that of 1604 . Wrd-Tzm-White Trp- recombinants (two tested) germinated only very slightly ( 5 to $7 \%$ fall in absorbance in $90 \mathrm{~min}$ ). Therefore the Wrdmutation is not responsible for the defective germination, although it appears that a mutation (or mutations) responsible for the germination phenotype may be located in the same region. The characteristics of this ger mutation must be examined in recombinants in which it has been separated from the Wrd and Tzm mutations of 1558.

The GerG mutant. Of a number of mutants lacking glycolytic enzymes (Prasad et al., 1972) only one, a 3-phosphoglycerate kinase ( $\left.\mathrm{PGK}^{-}\right)$mutant also produced spores that had lost the ability to germinate in ALA $+\mathrm{KCl}$ without the addition of GLC and FRU. The PGK mutation has been mapped by three factor crosses (Table 5, crosses 3, 4 and 5) using the requirement of $\mathrm{PGK}^{-}$strain 61111 for both glucose and malate as carbon sources (Freese et al., 1972) to select PGK+ transductants or to score PGK+ and PGK-. The data are consistent with the location of the PGK- mutation between cys $B$ and his $A$. Cotransduction frequencies of PGK with $\operatorname{thr}(9 \%)$, with $\operatorname{cys} B(58 \%)$ and with hisA $(38 \%)$ are also consistent with this map position.

The germination phenotype of the PGK mutant (Prasad et al., 1972) is somewhat similar to that of the GerA mutants (Trowsdale \& Smith, 1975; Lafferty \& Moir, 1977). The ger mutations in GerA strains, however, are located quite separately from that responsible for the PGK deficiency, and GerA strains do not lack a glycolytic enzyme since their growth on glucose is normal.

\section{Mutants altered in response to all three germinants}

GerD mutants. The mutations ger-19, ger-20 and ger-37 are responsible for defective germination in $\mathrm{PAB}$, in $\mathrm{ALA}+\mathrm{KCl}$ and in $\mathrm{ASN}+\mathrm{GLC}+\mathrm{FRU}+\mathrm{KCl}$ (Table 2). They were co-transduced, in two factor crosses with Mu8u5u16u24, 1612 and BD112, with purA (4 to $10 \%$ ), with aroI (10 to $18 \%$ ) and with $\operatorname{cys} A$ ( 77 to $88 \%$ ), respectively. Cys ${ }^{+}$recombinants were selected in the presence of methionine (Piggot, 1973) in three factor crosses with 4248 (cys $A$ ery-1) as recipient (Table 5, crosses 6, 7 and 8). The order of markers which can be deduced is cysA-ery-ger for all three mutants. 
Confirmation of the germination phenotype of transductants (performed for ger-20 and ger-37) was difficult. Erythromycin-sensitive (Ery $\left.{ }^{\mathrm{S}}\right)$ strains sporulate normally at $42{ }^{\circ} \mathrm{C}$, and spores of the Ery ${ }^{\mathrm{s}}$ transductants, both Tzm-White and Tzm-Red, produced at $42^{\circ} \mathrm{C}$ possessed the original mutant and wild type germination properties, respectively. However, erythromycin-resistant $\left(\right.$ Ery $\left.^{\mathrm{R}}\right)$ strains sporulate very poorly at $42^{\circ} \mathrm{C}$ (Tipper et al., 1977). To overcome this, spores were prepared at $26^{\circ} \mathrm{C}$ from transductants of all four recombinant classes where available. None of these spores germinated in ALA or in ASN + GLC + FRU $+\mathrm{KCl}$, but spores from Tzm-Red Ery ${ }^{\mathrm{S}}$ and Ery ${ }^{\mathrm{R}}$ transductants germinated in PGYE broth if heat-activated at $80^{\circ} \mathrm{C}$ for $10 \mathrm{~min}$, whereas spores of Tzm-White transductants did not. Thus the Ger ${ }^{-}$phenotype scored by the tetrazolium response was still associated with a decrease in ability to germinate. The map location of the ger mutants was therefore validated, although the recipient strain 4248 possessed a sporulation temperature-dependent deficiency in germination. Since this deficiency was retained by all transductants tested, it did not map close to cys $A$.

The GerE mutant. Strain 4600 (ger-36) did not germinate in any of the three test germinants. The ger mutation was not co-transduced with either cys $B$ or cys $A$. It was cotransduced with aroA $(23 \%), \arg A(35 \%), \operatorname{leu} A(92 \%)$ and phe $A(59 \%)$ in two factor crosses using recipients WB2281b, BD40, GSY374 and BD40, respectively. The order $\arg A$-ger-36-leuA-pheA was established in three point crosses (Table 5, crosses 9 and 10). The recipients in these crosses were constructed by transduction of BD40 to Ger- $\mathrm{Arg}^{+}$ and $\mathrm{Ger}^{-} \mathrm{Phe}^{+}$, respectively, by a lysate grown on strain 4600 .

The frequency of co-transduction of ger-36 with citF2 was 93\% (Table 5, cross 11). Since the number of $\mathrm{Ger}^{+}$transductants was very low, the assignment of a gene order to ger, cit and arg must remain tentative. The most probable order, however, is arg-ger-36citF2. Ger-36 was co-transduced with leu and citF78 [not with citF78 alone, as reported by Smith et al. (1978)] at a frequency of over $99 \%$; the ger mutation may be close to citF or between citF78 and leu. Strain 4600 and recombinants carrying ger-36 in the genetic background of BD40 appeared normal in vegetative growth both in rich and minimal media and, unlike citF strains, grew at the same rate as the wild type on MA plus lactate and formed purple colonies on NA-bromocresol purple agar (Carls \& Hanson, 1971).

Ger-36 was the only ger mutation observed to affect spore formation. Spores of the

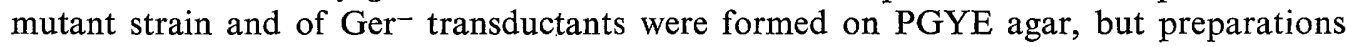
contained up to $50 \%$ of cells which had not formed phase-bright prespores. The spores appeared normally phase-bright but were smaller than those from $\mathrm{Ger}^{+}$strains and were frequently not released from the sporangium. The progress of sporulation of ger-36 strains in resuspension sporulation medium (Sterlini \& Mandelstam, 1969) was monitored (A. Moir, unpublished results). Populations of $\mathrm{Ger}^{+}$and $\mathrm{Ger}^{-}$cells initiated sporulation in synchrony, but at $42{ }^{\circ} \mathrm{C} \mathrm{ger-36}$ strains produced partially bright forespores which did not develop normal resistance to heat or to organic solvents and did not accumulate dipicolinic acid. At $26^{\circ} \mathrm{C}$ sporulation of ger-36 strains proceeded to completion. Spores, whether produced at $26^{\circ} \mathrm{C}$ in resuspension sporulation medium or at 26 or $42{ }^{\circ} \mathrm{C}$ on PGYE agar, were defective in germination in all three germinants. Electron microscopy of thin sections of ger-36 spores (A. Moir \& G. Dring, unpublished results) showed that the coat layers were incomplete in the mutant. The lysozyme-sensitivity and altered germination behaviour of ger-36 spores was reminiscent of the properties of coat-defective mutants of Bacillus cereus (Aronson \& Fitz-James, 1975; Cheng et al., 1978).

GerF mutants. Spores of strains 4595 and 4728 (carrying ger-21 and ger-45, respectively) germinated poorly in all three germinants tested (Table 2). Spores of strains carrying ger- 21 germinated to some extent in $\mathrm{PAB}$ and $\mathrm{ALA}+\mathrm{KCl}(25$ and $15 \%$ fall in absorbance in $60 \mathrm{~min}$, respectively) if they were produced at $26^{\circ} \mathrm{C}$, although the fall in absorbance was 
only $10 \%$ in each case if the spores were produced at $42{ }^{\circ} \mathrm{C}$. Spores of strains carrying ger-45 did not germinate in any of the three germinants ( $<5 \%$ fall in absorbance in $60 \mathrm{~min})$, irrespective of the temperature of sporulation.

In crosses with BD111 and BD92 as recipients, ger-21 and ger-45 were not co-transduced with $t h r$, but were 16 and $31 \%$ co-transduced with $c y s B$, and 93 and $89 \%$ co-transduced with his $A$, respectively. Three factor crosses between strain 1420 and ger-21 cysB3 trpC2 (constructed by transduction of BD92 to $\mathrm{His}^{+} \mathrm{Ger}^{-}$by a phage lysate grown on 4595) and between BD92 and 4728 were carried out (Table 5, crosses 12 and 13). In cross 12, 17\% of $\mathrm{His}^{+}$transductants were $\mathrm{Cys}^{-}$; in order to determine the proportions of $\mathrm{Ger}^{+}$and $\mathrm{Ger}^{-}$ phenotypes amongst both $\mathrm{Cys}^{+}$and $\mathrm{Cys}^{-}$transductants with reasonable accuracy, additional Cys $^{-}$transductants were screened for germination phenotype and are included in the data in Table 5 . This was not necessary for cross 13 , where the co-transduction of $c y s B$ and his $A$ was more frequent. In both crosses, no rare class of recombinant phenotypes was observed; the unequal distribution in the classes was consistent with the high frequency of co-transduction of ger with hisA. The sequence cysB-hisA-(ger-21, -45) can thus be deduced from the three factor crosses. This result is consistent with the two factor analysis and with further three factor crosses between BD92 and 4595 (A. Moir, unpublished results).

\section{DISCUSSION}

The mutants described were isolated as defective in response to at least one of three test germinants. However, a random sample of germination mutants has not been studied. All mutants were required to grow and sporulate on PGYE agar, only a limited variety of germinants were used for enrichment, and only strains which could be distinguished by the tetrazolium overlay method or by replica plating were examined. In addition those mutants whose spores responded to an intermediate extent to germinants at the concentrations used were not chosen for detailed analysis. How likely is it that the complex Gerphenotypes of the mutants result from single mutations? Genetic analysis has involved the transfer of ger mutations by transduction into an unmutagenized background. While this does not prove that the Ger- phenotype observed in transductants is the result of a single mutation, it does imply that if multiple mutations are responsible, they are located close together on the chromosome, since they were not separated in any of the recombinants whose phenotype was tested.

Accepting these limitations, the new mutants, along with those of Trowsdale \& Smith (1975), can still be conveniently subdivided according to the pattern of their response to the germinants, namely mutants germinating in ASN + GLC + FRU + KCl but not ALA, those germinating in ALA but not in ASN + GLC+FRU $+\mathrm{KCl}$ and those not germinating in either ALA or ASN + GLC + FRU + KCl (Table 2). Ger mutations have been located in six different regions of the $B$. subtilis 168 chromosome; if the PGK- mutant (Prasad et al., 1972) is included the number is seven. Ger mutations mapping in the same region have similar effects on the germination phenotype, although mutations in several different regions can be responsible for similar germination phenotypes. The distribution of mutants between groups and locations is extremely uneven. Of the 28 mutants whose spores were altered specifically in their germination response only to ALA, 26 map close together near cit $G$ between $t h r$ and $c y s B$ (the GerA group). They may represent a gene or group of genes particularly important in the germinative response to ALA. The other two, GerC mutants, are located in the lys-trp region. Representatives of other locations are also few. The one GerB mutant is altered in response to $\mathrm{ASN}+\mathrm{GLU}+\mathrm{FRU}+\mathrm{KCl}$ and maps on the originproximal side of his $A$ and the PGK ${ }^{-}$mutant (GerG) maps between $c y s B$ and his $A$. Among six mutants deficient in response to ALA, ASN + GLC + FRU $+\mathrm{KCl}$ and PAB, the GerD mutants map near cys $A$ and the GerE and GerF mutants close to citF and his $A$, respectively. Since mutants with this germination phenotype are so few and already three map 
locations have been recognized this could well mean that more than three genes are involved in the response of spores to these germinants.

Thus, interpretation of the available data in terms of the number and properties of genes involved in germination remains speculative. In addition, no fine structure mapping has yet been performed for mutations, like the GerA group, which are closely linked. The inability to select for either the $\mathrm{Ger}^{+}$or $\mathrm{Ger}^{-}$phenotype means that comparison of different ger mutations by the recombination index method (Lacks \& Hotchkiss, 1960) will be time consuming. Even after such analysis, it would not be possible to assign individual gene designations with confidence unless complementation analysis between ger mutants is performed. Merodiploidy is at present limited to certain regions of the $B$. subtilis chromosome (Karmazyn et al., 1973; Trowsdale \& Anagnostopoulos, 1976) but the cloning of genes into plasmids which are stably maintained in $B$. subtilis provides a promising alternative (Keggins et al., 1978). GerA and GerE mutants are located very close to cit genes (Table 5); thus the possibility of relationships between ger genes and these closely linked genes can be explored. Other aspects of the genetic analysis, such as the identification of nonsense mutations, the analysis of revertants and the identification of suppressor loci are now being attempted.

Some consideration of the nature of the deficiencies of Ger mutants in relation to possible mechanisms of spore germination is justified. The germination of spores of ger mutants is either conditional on the germinant used (GerA, B, C and G) or is defective in responses to the three germinants tested (GerD, E and F). GerA mutants do not respond to ALA, although response to the germinative combination of $\mathrm{ASN}+\mathrm{GLC}+\mathrm{FRU}+\mathrm{KCl}$ remains normal. Thus the response to ALA involves a component, altered in GerA mutants, which is not required for the response to $\mathrm{ASN}+\mathrm{GLC}+\mathrm{FRU}+\mathrm{KCl}$. The germination response of the GerB mutant suggests that the converse is also true. The efficiency of an interaction between germinant and a germinant-specific receptor or of the germinant-specific transduction of the initial stimulus may be altered in these GerA and B mutants (Smith et al., 1978). This deficiency is unlikely to be in the general permeability of the spore to small molecules or in any critical enzyme effecting hydrolytic changes observed in the spore during germination unless these were germinant-specific. GerA and B germination properties could be the result of mutational blocks in the metabolism of germinants in the spore. However, any deficiency in the metabolism of glucose or alanine by the mutants is not sufficient to affect their utilization as carbon sources by vegetative cells (A. Moir, E. Lafferty \& R. Sammons, unpublished). The defects in GerD, E and F mutants appear to be more general in nature (although testing a wider spectrum of germinants may reveal that some of these, too, are conditional). The mutations could affect a molecule whose role is common to a wide variety of germinants such as a common receptor or transducer of the germination stimulus, or a regulatory molecule controlling the synthesis of proteins important in germination. Alternatively, they could affect spore structure and have an indirect effect on germination, perhaps by decreasing the permeability of the outer layers of the spore to germinants, or by decreasing the accessibility of receptor sites. Mutant spores could fail to provide the structure in which macromolecules important in germination may be located, or fail to produce germination-associated proteins because of alterations in the pattern of gene expression during sporulation. Only in the GerE mutant has any actual structural abnormality been identified.

The mapping of ger mutations provides information of considerable importance to comparisons between $\mathrm{Ger}^{-}$mutant phenotypes, and relevant to the development and testing of theories of germination. The knowledge that different gene products are altered in mutants of similar phenotype may help to qualify any theories based on the properties of such mutants. Likewise, similarities and differences in phenotypes of mutants may assume increased significance if they are known to map very closely together. Identification of the nature and role of the altered gene products will require a much more detailed 
analysis of the physiology and biochemistry of the mutants than has so far been carried out. However, the work described should provide a basis for an approach to the analysis of germination complementary to biochemical studies of normal germination.

The work was supported by an SRC research grant to D.A.S. and CASE studentship to E. L. We are grateful to Hazel Howell and Sue Thomas for technical assistance and to Jane Calvert and Teresa Bovingdon for the isolation of ger-45 during an undergraduate project. We thank all those who sent us bacterial strains, and Mr G. Dring, Professor G. W. Gould, Drs J. Trowsdale and P. Piggot for valuable discussion.

\section{REFERENCES}

Anagnostopoulos, C. \& Spizizen, J. (1961). Requirements for transformation in Bacillus subtilis. Journal of Bacteriology 81, 741-746.

Aronson, A. \& Fitz-James, P. C. (1975). Properties of Bacillus cereus spore coat mutants. Journal of Bacteriology 123, 354-365.

CARls, R. A. \& Hanson, R. S. (1971). Isolation and characterisation of tricarboxylic acid cycle mutants of Bacillus subtilis. Journal of Bacteriology 106, 848-855.

Cheng, Y.-S. E., Fitz-James, P. \& Aronson, A. I. (1978). Characterisation of a Bacillus cereus protease mutant defective in an early stage of spore germination. Journal of Bacteriology 133, 336-344.

Dring, G. J. \& Gould, G. W. (1971). Movement of potassium during L-alanine-initiated germination of Bacillus subtilis spores. In Spore Research 1971, pp. 133-141. Edited by A. N. Barker, G. W. Gould \& J. Wolf. London: Academic Press.

Foerster, C. W. \& Foerster, H. F. (1973). Glutamic acid decarboxylase in spores of Bacillus megaterium and its possible involvement in spore germination. Journal of Bacteriology 114, 1090-1098.

Foerster, H. F. (1971). $\gamma$-Aminobutyric acid as a required germinant for mutant spores of Bacillus megaterium. Journal of Bacteriology 108, 817-823.

Freese, E., OH, Y. K., Freese, E. B., Diesterhaft, M. D. \& Prasad, C. (1972). Suppression of sporulation of Bacillus subtilis. In Spores $V$, pp. 212-221. Edited by H. O. Halvorson, R. Hanson \& L. L. Campbell. Washington, D.C.: American Society for Microbiology.

Galizzi, A., Gorrini, F., Rollier, A. \& PolsiNELLI, M. (1973). Mutants of Bacillus subtilis temperature sensitive in the outgrowth phase of spore germination. Journal of Bacteriology 113, 1482-1490.

Galizzi, A., Siccardi, A. G., Albertini, A. M., Amileni, A. R., Meneguzzi, G. \& Polsinelli, M. (1975). Properties of Bacillus subtilis mutants temperature sensitive in germination. Journal of Bacteriology 121, 450-454.

Goldthwaite, C., Dubnau, D. \& Smith, I. (1970). Genetic mapping of antibiotic resistance markers in Bacillus subtilis. Proceedings of the National Academy of Sciences of the United States of America 65, 96-103.

Gould, G. W. (1969). Germination. In The Bucterial
Spore, pp. 397-444. Edited by G. W. Gould \& A. Hurst. London: Academic Press.

Jamet, C. \& Anagnostopoulos, C. (1969). Etude d'une mutation très faiblement transformable au locus de la thréonine désaminase de Bacillus subtilis. Molecular and General Genetics 105, 225242.

Karmazyn, C., Anagnostopoulos, C. \& SchaefFER, P. (1973). Caractère récessif de certaines mutations affectant la sporulation. Annales de Microbiologie 124B, 125-138.

Keggins, K. M., LovetT, P. S. \& Duvall, E. J. (1978). Molecular cloning of genetically active fragments of Bacillus DNA in Bacillus subtilis and properties of the vector plasmid pUB110. Proceedings of the National Academy of Sciences of the United States of America 75, 1423-1427.

Keynan, A. \& Halvorson, H. (1965). Transformation of a dormant spore into a vegetative cell. In Spores III, pp. 174-179. Edited by L. L. Campbell \& H.O. Halvorson. Ann Arbor: American Society for Microbiology.

LACKs, S. \& Hotchisiss, R. (1960). A study of the genetic material determining an enzyme activity in Pneumococcus. Biochimica et biophysica acta 39, 508-518.

LAFFERTY, E. \& MoIR, A. (1977). Further studies on conditional germination mutants of Bacillus subtilis 168. In Spore Research 1976, pp. 87-105. Edited by A. N. Barker, J. Wolf, D. J. Ellar, G. J. Dring \& G. W. Gould. London: Academic Press.

Nester, E. W., Schafer, M. \& Lederberg, J. (1963). Gene linkage in DNA transfer: a cluster of genes concerned with aromatic biosynthesis in Bacillus subtilis. Genetics 48, 529-551.

Nukushina, J.-I. \& IkedA, Y. (1969). Genetic analysis of the developmental processes during germination and outgrowth of Bacillus subtilis spores with temperature-sensitive mutants. Genetics 63, 63-74.

OHné, M., Rutberg, B. \& Hoch, J. A. (1973). Genetic and biochemical characterisation of mutants of Bacillus subtilis defective in succinate dehydrogenase. Journal of Bacteriology 115, 738745.

PIgGot, P. J. (1973). Mapping of asporogenous mutations of Bacillus subtilis: a minimum estimate of the number of sporulation operons. Journal of Bacteriology 114, 1241-1253.

PIgGot, P. J. \& Coote, J. G. (1976). Genetic as- 
pects of bacterial endospore formation. Bacteriological Reviews 40, 908-962.

Prasad, C., Diesterhaft, M. \& Freese, E. (1972). Initiation of spore germination in glycolytic mutants of Bacillus subtilis. Journal of Bacteriology 110, 321-328.

RutberG, B. \& Hoch, J.A. (1970). Citric acid cycle: gene-enzyme relationships in Bacillus subtilis. Journal of Bacteriology 104, 826-833.

SMITH, D. A., MoIr, A. \& LAFFerTy, E. (1977). Spore germination genetics in Bacillus subtilis. In Spore Research 1976, pp. 69-85. Edited by A. N. Barker, J. Wolf, D. J. Ellar, G. J. Dring \& G. W. Gould. London: Academic Press.

Smith, D. A., Molr, A. \& SAmmons, R. (1978). Progress in genetics of spore germination in Bacillus subtilis. In Spores VII, pp. 158-163. Edited by G. Chambliss \& J. C. Vary. Washington, D.C.: American Society for Microbiology.

Sterlini, J. M. \& Mandelstam, J. (1969). Commitment to sporulation in Bacillus subtilis and its relationship to actinomycin resistance. Biochemical Journal 113, 29-37.

Tipper, D. J., Johnson, C. W., Ginther, C. L., Leighton, T. \& Wittman, H. G. (1977). Erythromycin resistant mutations in Bacillus subtilis cause temperature sensitive sporulation. Molecular and General Genetics 150, 147-159.
Trowsdale, J. \& Anagnostopoulos, C. (1976). Differences in the genetic structure of Bacillus subtilis strains carrying the $\operatorname{trp} E 26$ mutation and strain 168. Journal of Bacteriology 126, 609-618.

Trowsdale, J. \& Smith, D. A. (1975). Isolation, characterisation and mapping of Bacillus subtilis 168 germination mutants. Journal of Bacteriology 123, 83-95.

Trowsdale, J., Smith, D. A. \& Gould, G. W. (1974). Mapping of germination mutants of Bacillus subtilis 168. In Spore Research 1973, pp. 103-117. Edited by A. N. Barker, G. W. Gould \& J. Wolf. London: Academic Press.

VARY, J. (1975). Properties of Bacillus megaterium temperature-sensitive germination mutants. Journal of Bacteriology 121, 197-203.

WAX, R. \& FREESE, E. (1968). Initiation of the germination of Bacillus subtilis spores by a combination of compounds in place of $\mathrm{L}$-alanine. Journal of Bacteriology 95, 433-438.

WAX, R., Freese, E. \& CASHel, M. (1967). Separation of two functional roles of L-alanine in the initiation of Bacillus subtilis spore germination. Journal of Bacteriology 94, 522-529.

Woese, C. R., Morowitz, H. J. \& Hutchinson, C. A. (1958). Analysis of the action of L-alanine analogues in spore germination. Journal of Bacteriology 76, 578-588. 